\title{
Analisis Clustering Penduduk Miskin Di Provinsi Aceh Menggunakan Algoritma K-Means Dan X-Means
}

\author{
Bustami Yusuf ${ }^{1}$, Rike Mahara $^{2}$, Hendri Ahmadian $^{3}$, Sri Wahyuni ${ }^{4}$, Khairan $\mathrm{AR}^{5}$ \\ ${ }^{1,3,4}$ Program Studi Teknologi Informasi, ${ }^{2,5}$ Program Sudi Pendidikan Teknologi Informasi \\ Universitas Islam Negeri Ar-Raniry Banda Aceh \\ Corresponding author's e-mail: bustamiyusoef@ar-raniry.ac.id
}

\begin{abstract}
Abstrak-Analisis Clustering merupakan salah satu metode yang bertujuan untuk mengelompokan data/objek berdasarkan kemiripan dan ketidakmiripan karakteristiknya. Sehingga objek yang berada pada satu cluster memiliki kemiripan yang besar dan sangat kecil bila dibandingkan dengan cluster lain. Algoritma $K$-means merupakan salah satu metode pengelompokan non hierarki yang paling umum digunakan, namun pada algoritma ini pengguna harus mengetahui jumlah kelompok yang akan dikelompokan. Sedangkan algoritma $X$ means merupakan pengembangan dari algoritma $K$-means, dimana algoritma ini mampu mengelompokan datanya sendiri tanpa menginput jumlah k. Algoritma $X$-means akan berhenti melakukan pengelompokan hingga batas cluster maksimal tercapai. Algoritma $X$-means juga tau kapan dan dimana centroid baru harus muncul berdasarkan perhitungan nilai Bayesian Information Criterion (BIC). Penelitian ini bertujuan untuk membandingkan hasil analisis clusteringK-means dengan $X$-means menggunakan data penduduk miskin provinsi Aceh tahun 2018 dan data Iris. Hasil pengujian clustering dengan data Iris memiliki tingkat kemurnian dan hasil pengelompokan yang baik dari masing-masing algoritma. Yaitu nilai purity pada $K$-means sebanyak 0.89 dan pada X-means 0.88 dengan nilai Davies Bouldin Index (DBI) masing-masing 0.16. Dan hasil pengujian clustering dengan data penduduk miskin menunjukkan bahwa pada algoritma $K$-means didapatkan tingkatan kemiskinan dengan kategori Sangat Miskin berada pada cluster nol, kategori Miskin pada cluster dua, kateogori Rentan Miskin berada pada cluster tiga dan kategori Tidak Miskin berada pada cluster satu. Dan pada algoritma $X$-means diperoleh tingkatan kemiskinan dengan kategori Sangat Miskin berada pada cluster satu, kategori Miskin pada cluster tiga, kategori Rentan Miskin berada pada cluster dua dan kategori Tidak Miskin berada pada cluster nol. Berdasarkan Waktu yang dibutuhkan selama proses clustering algoritma $X$ means memiliki kecepatan yang lebih baik yaitu 0.06 second. Sedangkan $K$-means membutuhkan waktu selama 0.22 second. Sehingga dapat disimpulkan bahwa algoritma $X$-means lebih cepat dalam melakukan pengelompokan dibandingkan algoritma $K$-means.
\end{abstract}

Kata Kunci : Penduduk Miskin, K-means, X-means, Purity, Davies Bouldin Index (DBI)

\section{Pendahuluan}

Kemiskinan adalah suatu masalah serius yang sudah ada dari generasi ke generasi. Kemiskinan merupakan suatu keadaan yang berada dibawah standar kebutuhan minimum, baik dalam bidang makanan dan bukan makanan yang disebut sebagai garis kemiskinan[1]. Dimana khusus wilayah Sumatera pada tahun 2018 angka kemiskinan tertinggi berada di provinsi Aceh yaitu sebesar 15,68\% dan angka terendah berada di Kepulauan Riau yaitu sebesar $4,77 \%$ [2].

Bila dilihat secara nasional Aceh merupakan provinsi termiskin ke-6. Pemerintah Aceh giat memberikan bantuan sosial berbasis keluarga seperti beasiswa untuk anak yatim[3], Jaminan Kesehatan Aceh (JKA)[4], serta membangun dan merehab rumah penduduk miskin[5]. Kendala utama yang dihadapi adalah persoalan penargetan, khususnya penargetan individu atau rumah tangga yang kurang mampu[6]. Oleh karenanya perlu dilakukan hal-hal yang lebih optimal serta menyeluruh dalam penanggulangan kemiskinan. Untuk itu diperlukan suatu cara pengelompokan data keluarga miskin yang lebih efisien agar pemerataan bantuan lebih tepat sasaran. Pengelompokan ini dapat diselesaikan dengan menggunakan salah satu metode dalam data mining, yaitu metode clustering[7]. Dengan metode clustering pengelompokkan data dapat dilakukan dengan lebih akurat sesuai dengan tingkat kemiripan dari karakteristik datanya[8]. Ada beberapa algoritma clustering yang dapat digunakan untuk mengelompokan data, diantaranya algoritma k-means dan $x$-means[9].

\section{Dasar Teori}

\subsection{Clustering}

Clustering atau pengelompokan merupakan suatu teknik dalam data mining yang digunakan untuk menganalisis data yang bertujuan untuk memecahkan permasalahan dalam pengelompokan data atau lebih tepatnya memisahkan dari dataset ke dalam subset[10]. Dalam pengelompokan suatu objek, teknik ini hanya berdasarkan pada tingkat kemiripan karakteristik dari suatu atribut pada data objek. Dengan demikian, data 
objek akan memiliki tingkat kemiripan yang sama di dalam cluster yang sama, serta memiliki kemiripan yang berbeda di antara cluster yang berbeda. Terdapat 2 jenis metode pada clustering yaitu hierarchical clustering dan non-hierarchical clustering[11]. Dan algoritma K-means merupakan salah satu metode dari nonhierarchical clustering.

\section{$2.2 \mathrm{~K}$-means}

K-means pertama kali diperkenalkan oleh MacQueen JB pada tahun 1976. Algoritma K-meansmerupakan salah satu metode non-hirarchiyang sangat umum digunakan. algoritma ini akan melakukan pengelompokan dengan teknik membagi atau memisahkan objek ke k lain[1].

Algoritma $K$-means sering digunakan karena memiliki kemampuan dalam mengelompokan jumlah data yang besar dengan waktu yang cepat dan efisien[12]. Algoritma K-means menentukan pusat cluster (centroid) awal secara random, sehingga hasil pengelompokan yang didapat tidak menjanjikan hasil yang khas. Karena penentuan titik pusat (centroid) awal sangat bergantung pada efisiensi keaslian algoritma $K$-means. Tahapan yang dilakukan pada algoritma K-means yaitu sebagai berikut :

1. Menentukan jumlah $\mathrm{k}$, dimana $\mathrm{k}$ merupakan jumlah cluster

2. Menetapkan nilai awal titik pusat clustersecara random k-record yang menjadi lokasi pusat cluster awal.

3. Setiap data akan dicari titik pusat cluster terdekatnya. Artinya setiap titik pusat cluster "memiliki" subset dari data, sehingga dapat merepresentasikan sebuah partisi dari dataset. Dan akan didapatkan k cluster yaitu $\mathrm{C} 1, \mathrm{C} 2, \ldots, \mathrm{Ck}$. Untuk menentukan data masuk ke C1, C2 dan seterusnya maka perlu dihitung jarak terdekat setiap data dengan titik pusat cluster. Untuk menghitung jarak setiap data digunakan teori jarak Euclidean yang dirumuskan sebagai berikut :

$$
D(i j)=\sqrt{\left(X_{1 i}-X_{1 j}\right)^{2}+\left(X_{2 i}-X_{2 j}\right)^{2}+. .+. .+\left(X_{k i}-X_{k j}\right)^{2}}
$$

$\mathrm{D}(\mathrm{i}, \mathrm{j})=$ Jarak data ke- $i$ ke pusat clusterj

$\mathrm{X}_{\mathrm{ki}}=$ Data ke- $i$ pada atribut data ke $k$

$\mathrm{X}_{\mathrm{kj}}=$ Titik pusat ke- $j$ pada atribut ke $k$

Setiap k cluster yang dihasilkan akan dicari centroidnya dan akan memperbaharui lokasi setiap pusat cluster untuk menghasilkan centroid baru. Untuk menentukan centroid baru digunakan persamaan berikut:

Keterangan :

$$
v_{i j}=\frac{1}{N_{i}} \sum_{k=0}^{n} x_{j}
$$

$v_{i j}=$ centroid/rata-rata cluster ke-i untuk variabel ke-j

$N_{i}=$ jumlah data yang menjadi anggota cluster ke-i

$i, k=$ indeks dari cluster

$j \quad=$ indeks dari variabel

$x_{i j}=$ nilai data ke- $k$ yang ada di dalam cluster tersebut untuk variabel ke-j

4. Ulangi langkah 3 sampai 5, sampai data tidak mengalami perpindahan.

Algoritma akan berhenti saat titik pusat cluster tidak lagi berubah. Artinya, algoritma berakhir ketika seluruh cluster $\mathrm{C} 1, \mathrm{C} 2, \ldots, \mathrm{Ck}$, semua record yang dimiliki oleh masing-masing pusat cluster tetap berada dalam cluster tersebut[13].

\section{$2.3 X$-means}

$X$-means merupakan algoritma penyempurnaan dari K-means. kesulitan dalam penentuan jumlah cluster yang digunakan serta waktu proses yang masih terhitung lama pada jumlah data yang besar dalam clustering sehingga mendorong penyempurnaan dari algoritma k-means ke algoritma $X$-means.

Proses kerja dari teknik ini adalah dengan mencari ruang diantara tempat cluster dan jumlah cluster untuk melakukan optimasi Bayesian Information Criterion (BIC) serta memberikan keputusan apakah centroid harus dibagi atau tidak. Proses ini hanya dapat digunakan untuk data Numeric[14]. Algoritma X-means terdiri dari dua operasi yang berulang hingga eksekusi berakhir, yaitu:

\section{Improve-Params}

Merupakan eksekusi algoritma K-means konvensional hingga mencapai konvergen atau tidak terjadi perpindahan point antar cluster. 
2. Improve-Structure

Menemukan jika dan di mana titik pusat cluster (centroid) baru harus muncul. Hal ini dicapai dengan membiarkan beberapa centroid dibagi menjadi dua berdasarkan BIC[15].

\section{Metode Penelitian}

\subsection{Tahapan Penelitian}

Pada sub bahasan tahapan penelitian akan dibahas mengenai tahapan-tahapan yang akan dilakukan dalam penelitian. Untuk tahapannya dapat dilihat pada gambar 1.

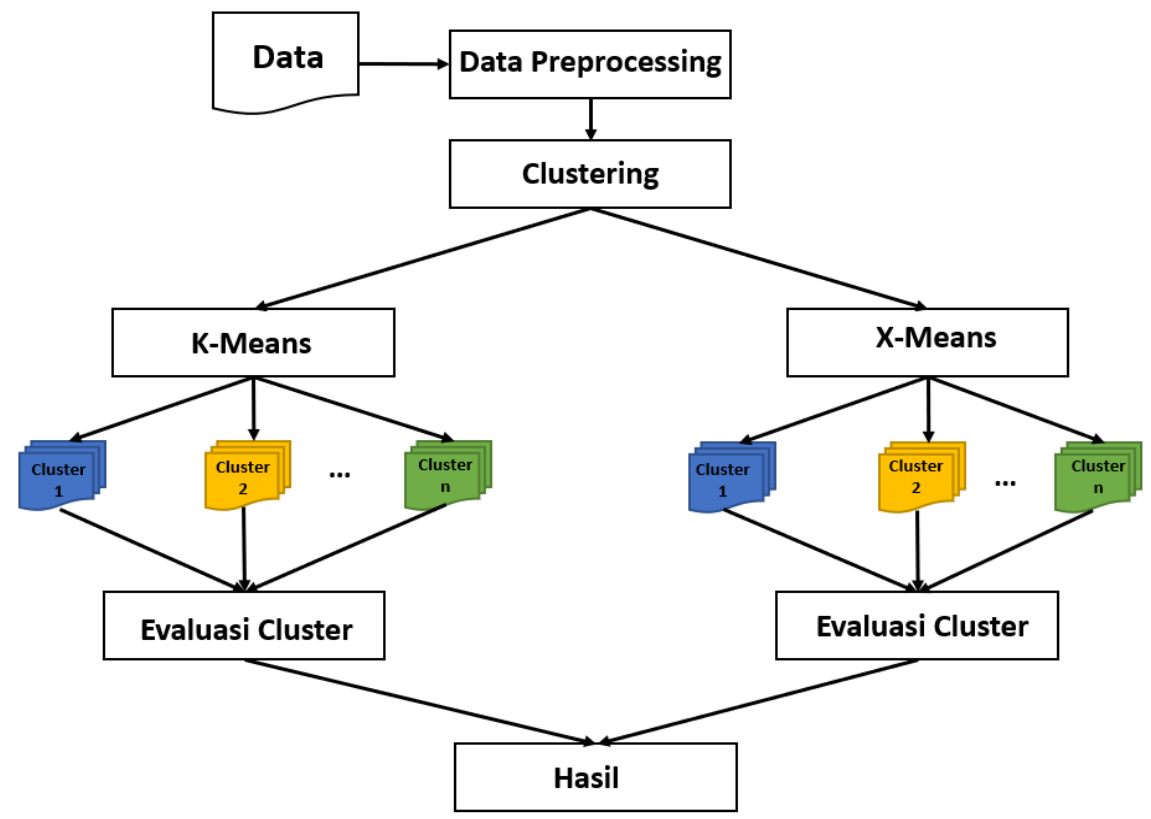

Gambar 1. Flowchart Metodologi Penelitian

\section{Data}

Pengumpulan data yang akan digunakan dalam penelitian ini yaitu data penduduk miskin di provinsi Aceh dan data Iris. Dimana data BPS digunakan untuk mengelompokan data dan data Iris digunakan untuk menguji keakuratan suatu cluster yang dihasilkan dari masing-masing algoritma.

Tabel 1. Data BPS

\begin{tabular}{|c|c|c|c|c|c|c|c|c|}
\hline \multicolumn{9}{|c|}{ 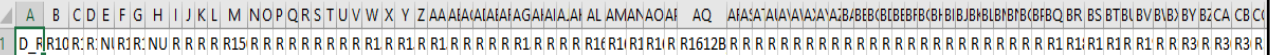 } \\
\hline 2 & 112215 & & 455143650000005 & & 000 & 00 & 005555555555555555555555551 & 2021202 \\
\hline & 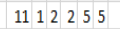 & & 1575 & & 00 & & 0 & 110182 \\
\hline 4 & 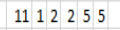 & 1 & 111075 & 515 & 000 & 0 & 005 & 110120 \\
\hline & 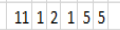 & 1 & $0002-250$ & 205 & 000 & 01700 & & 110140 \\
\hline 6 & 5 & 1 & 0005 & 515 & 000 & 00 & 555 & 1101413 \\
\hline & 5 & 11 & 000005 & 515 & 000 & 00 & & 1101404 \\
\hline 8 & & 17 & 100005 & 075 & 000 & 0 & & 1101303 \\
\hline & & & 5052436500000 & 62621100105150 & & 00 & 55555555555551555550 & 1101202 \\
\hline
\end{tabular}

Data penduduk miskin yang didapat dari Badan Pusat Statistik (BPS) Provinsi Aceh teridiri dari 88 variabel. Adapun jumlah data yang diterima adalah sebanyak 11.462 data. Tabel 1 merupakan contoh tampilan file dalam format excel yang diterima dari BPS dengan jumlah 88 variabel.

Data Iris merupakan data multivariat yang diperkenalkan oleh Sir Ronald Aylmer Fisher (1936) sebagai contoh analisis diskriminan. Data iris terdiri dari 4 variabel yang akan diukur yaituSepal Length, Sepal Width, Petal Length dan Petal Width. Dan memiliki 3 jenis bunga iris yaitu Iris-Setosa, Iris Versicolor dan Iris Virginica dengan jumlah data sebanyak 150 data[16]. Sampel data Iris ditampilkan dalam tabel 2. 
Tabel 2. Data Iris

\begin{tabular}{|c|c|c|c|c|}
\hline No & Sepal Length & Sepal Width & Petal Length & Petal Width \\
\hline 1 & 5.1 & 3.5 & 1.4 & 0.2 \\
\hline 2 & 4.9 & 3 & 1.4 & 0.2 \\
\hline 3 & 4.7 & 3.2 & 1.3 & 0.2 \\
\hline 4 & 4.6 & 3.1 & 1.5 & 0.2 \\
\hline 5 & 5 & 3.6 & 1.4 & 0.2 \\
\hline 6 & 5.4 & 3.9 & 1.7 & 0.4 \\
\hline 7 & 4.6 & 3.4 & 1.4 & 0.3 \\
\hline 8 & 5 & 3.4 & 1.5 & 0.2 \\
\hline 9 & 4.4 & 2.9 & 1.4 & 0.2 \\
\hline 10 & 4.9 & 3.1 & 1.5 & 0.1 \\
\hline
\end{tabular}

\section{Data Preprocessing}

Pada tahap ini dilakukan persiapan data untuk diproses di aplikasi Weka dengan memilih variabel yang berpengaruh serta membuang variabel yang tidak berpengaruh. Ada 2 tahap pemrosesan data yang dilakukan yaitu data selection dan data transformation.

Data selection atau seleksi data merupakan pemilihan data atau variabel yang akan digunakan dalam penelitian[17]. Adapun pada penelitian ini hanya melakukan proses seleksi pada variabel. Dimana jumlah variabel yang sebelumnya berjumlah 88 variabel, setelah dilakukan seleksimaka diperoleh 13 variabel. Variabel sebelum diseleksi dapat dilihat pada gambar 4 dan sesudah dilakukan seleksi dapat dilihat pada tabel dibawah :

Tabel 3. Variabel Setelah Diseleksi

\begin{tabular}{|c|c|c|c|c|c|c|c|c|c|c|c|c|c|c|c|}
\hline 4 & A & B & C & D & $E$ & & $F$ & G & $\mathrm{H}$ & 1 & J & & K & L & $M$ \\
\hline 1 & Kabupate & Kota/Desa & Status T.Tingga & L.Lantai & i Atap & & Dinding & Lantai & MCK & P.Tinja & SAM & & S.Penerangan & Jenis B.Bakar & K.Barang \\
\hline 2 & 1 & 2 & . & 1 & 45 & 4 & & 3 & 6 & 5 & 0 & 5 & 1 & 7 & 5 \\
\hline 3 & 1 & 2 & . & 1 & 40 & 4 & & 3 & 6 & 1 & 1 & 5 & 1 & 7 & 5 \\
\hline 4 & 1 & 2 & ? & 1 & 81 & 4 & & 3 & 6 & 2 & 1 & 5 & 1 & 7 & 5 \\
\hline 5 & 1 & 2 & & 1 & 40 & 4 & & 3 & 6 & 5 & 0 & 2 & 1 & 10 & 5 \\
\hline 6 & 1 & 2 & & 1 & 60 & 4 & & 3 & 6 & 5 & 0 & 5 & 1 & 10 & 5 \\
\hline 7 & 1 & 2 & . & 1 & 96 & 4 & & 1 & 6 & 5 & 0 & 5 & 1 & 7 & 5 \\
\hline 8 & 1 & 2 & . & 1 & 72 & 4 & & 1 & 2 & 4 & 0 & 5 & 1 & 7 & 5 \\
\hline 9 & 1 & 2 & & 3 & 50 & 4 & & 3 & 6 & 5 & 0 & 6 & 1 & 10 & 5 \\
\hline 10 & 1 & 2 & . & 1 & 60 & 4 & & 1 & 6 & 1 & 1 & 2 & 1 & 7 & 5 \\
\hline
\end{tabular}

Setelah data di seleksi dan telah didapatkan atribut yang mengacu kepada indikator kemiskinan. Selanjutnya data diubah ke dalam format yang bisa diterima di perangkat data mining yang akan memprosesnya[17]. Perangkat lunak data mining menerima format .csv. berhubung data yang diperoleh dalam format . $x l s$ maka bisa langsung disimpan dalam format .csv. Setelah data diubah ke dalam format .csv maka selanjutnya diubah ke dalam format .arff pada weka. Adapun tampilan data dalam format .csv dan .arff dapat dilihat pada gambar 1 dan gambar 2 :

\begin{tabular}{|l|} 
Kabupaten, Kota/Desa, Status \\
T.Tinggal, L.Lantai, Atap, Dinding, Lantai,MCK, P. Tinja, SAM, S. Penerangan, Jenis \\
B.Bakar, K. Barang \\
$1,2,1,45,4,3,6,5,0,5,1,7,5$ \\
$1,2,1,40,4,3,6,1,1,5,1,7,5$ \\
$1,2,1,81,4,3,6,2,1,5,1,7,5$ \\
$1,2,1,40,4,3,6,5,0,2,1,10,5$ \\
$1,2,1,60,4,3,6,5,0,5,1,10,5$ \\
$1,2,1,96,4,1,6,5,0,5,1,7,5$ \\
$1,2,1,72,4,1,2,4,0,5,1,7,5$ \\
$1,2,3,50,4,3,6,5,0,6,1,10,5$ \\
$1,2,1,60,4,1,6,1,1,2,1,7,5$ \\
\hline
\end{tabular}

Gambar 2. Data BPS dalam format .csv 


\begin{tabular}{|l|}
\hline @relation 'file BPS'@attribute Kabupaten numeric@attribute Kota/Desa numeric \\
@attribute 'Status T.Tinggal' numeric@attribute L.Lantai numeric@attribute \\
Atap numeric@attribute Dinding numeric@attribute Lantai numeric@attribute MCK \\
numeric@attribute P.Tinja numeric@attribute SAM numeric@attribute S.Penerangan \\
numeric@attribute 'Jenis B.Bakar' numeric@attribute K.Barang numeric@data \\
$1,2,1,45,4,3,6,5,0,5,1,7,5$ \\
$1,2,1,40,4,3,6,1,1,5,1,7,5$ \\
$1,2,1,81,4,3,6,2,1,5,1,7,5$ \\
$1,2,1,40,4,3,6,5,0,2,1,10,5$ \\
$1,2,1,60,4,3,6,5,0,5,1,10,5$ \\
$1,2,1,96,4,1,6,5,0,5,1,7,5$ \\
$1,2,1,72,4,1,2,4,0,5,1,7,5$ \\
$1,2,3,50,4,3,6,5,0,6,1,10,5$ \\
$1,2,1,60,4,1,6,1,1,2,1,7,5$ \\
$1,2,1,46,7,3,6,5,0,5,1,10,5$ \\
$1,2,1,32,4,3,6,1,1,2,1,1,5$ \\
$1,2,1,90,4,3,2,1,3,8,1,1,5$
\end{tabular}

Gambar 3. Data BPS dalam format .arrf

\section{Hasil dan Pembahasan}

\subsection{Pengujian Algoritma $K$-means dan $X$-means}

\section{Data Iris}

Berdasarkan hasil pengujian dengan data Iris maka didapatkan hasilnya seperti yang ditampilkan dalam tabel 4.

Tabel 4. Nilai Purity dan DBI Data Iris

\begin{tabular}{|l|c|c|c|c|c|c|c|c|}
\hline \multirow{2}{*}{$\begin{array}{c}\text { Algoritma/ } \\
\text { Metode }\end{array}$} & \multicolumn{5}{|c|}{ K-Means } & \multicolumn{5}{c|}{ X-Means } \\
\cline { 2 - 9 } & C1 & C2 & C3 & Total & C1 & C2 & C3 & Total \\
\hline Purity & 0.94 & 1 & 0.72 & $\mathbf{0 . 8 9}$ & 0.84 & 0.80 & 1 & $\mathbf{0 . 8 8}$ \\
\hline DBI & & & & $\mathbf{0 . 1 6}$ & & & & $\mathbf{0 . 1 6}$ \\
\hline
\end{tabular}

Dari tabel diatas dapat dilihat nilai purity pada masing-masing algoritma tidak berbeda jauh. Nilai purity tertinggi pada cluster menggunakan algoritma K-means adalah pada $\mathrm{C} 2$ dan menggunakan $X$-means nilai purity tertinggi yaitu pada C3. Dari tabel 4 diperoleh grafik sebagai berikut :

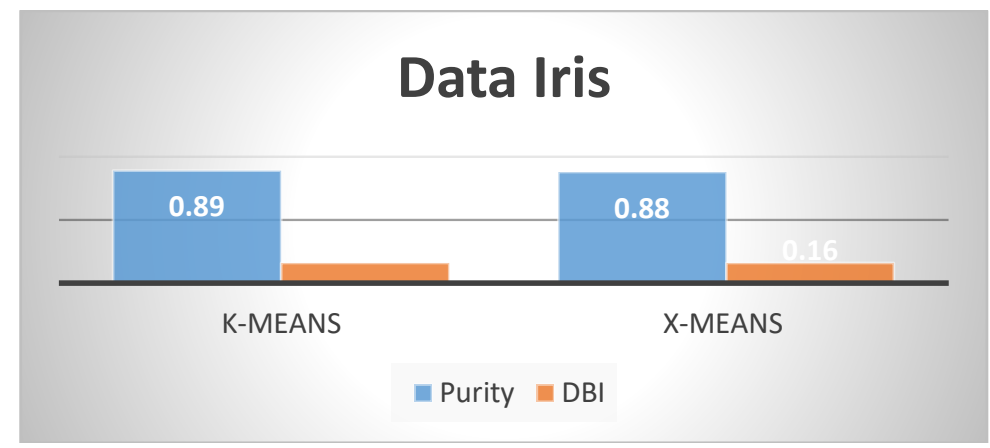

Gambar 5. Nilai purity dan DBI data Iris

Berdasarkan grafik diatas dapat dilihat bahwanilai purity pada $K$-means yaitu 0.89 dan pada $X$-means 0.88 dan untuk nilai DBI tidak terdapat perbedaan yaitu sama-sama mendapatkan nilai 0.16.

\section{Data Badan Pusat Statistik (BPS)}

Pada tahap ini akan dilakukan pengelompokan data BPS dengan menggunakan aplikasi Weka. Data akan dikelompokan menjadi 4 cluster. Adapun hasil yang diperoleh dapat dilihat pada tabel dibawah : 
Tabel 5. Hasil Cluster menggunakan K-means dan X-means

\begin{tabular}{|c|c|c|c|}
\hline \multicolumn{2}{|c|}{ K-means } & \multicolumn{2}{c|}{ X-means } \\
\hline Cluster & Jumlah Data & Cluster & Jumlah Data \\
\hline 0 & 2507 & 0 & 5672 \\
\hline 1 & 1686 & 1 & 3262 \\
\hline 2 & 4732 & 2 & 703 \\
\hline 3 & 2537 & 3 & 1825 \\
\hline
\end{tabular}

Dari hasil cluster diatas dapat divisualisasikan pada gambar plot dibawah :

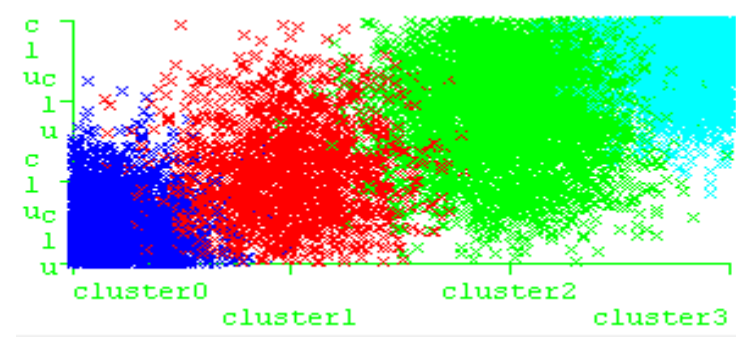

Gambar 6. Visualisasi cluster dengan K-means

Dari gambar 6 visualisasi plot diatas dan berdasarkan tabel 5 dapat dilihat bahwa hasil pengelompokan menggunakan algoritma $K$-meansdiketahui bahwa jumlah data pada cluster 0 (warna biru) adalah sebanyak 2507, pada cluster 1 (warna merah) berjumlah 1686, pada cluster 2 (warna hijau) berjumlah 4732 data dan pada cluster 3 (warna biru muda) berjumlah 2537 data.

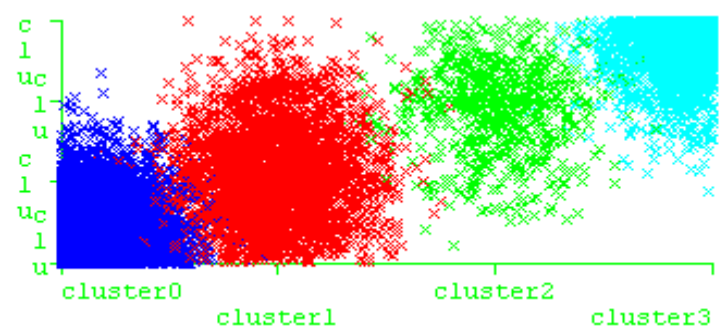

Gambar 7. Visualisasi Cluster dengan X-means

Dari gambar 7 visualisasi plot dapat dilihat bahwa hasil pengelompokan menggunakan algoritma $X$-means diketahui bahwa jumlah data pada cluster 0 (warna biru) adalah sebanyak 5672, pada cluster 1 (warna merah) berjumlah 3262, pada cluster 2 (warna hijau) berjumlah 703 data dan pada cluster 3 (warna biru muda) berjumlah 1825 data.

Waktu yang dibutuhkan algoritma $K$-means dalam melakukan pengelompokan yaitu selama 0.22 second dengan jumlah iterasi sebanyak 6 iterasi, sedangkan pada algoritma $X$-means yaitu selama 0.06 second dengan jumlah iterasi sebanyak 1 iterasi.

\subsection{Analisis Hasil Clustering}

\section{Kategori}

Kategori merupakan istilah, tanda, simbol yang dimaksudkan untuk mengenali suatu data atau kelompok 1 dengan yang lainnya[18]. Pada penelitian ini dilakukan proses kategori untuk setiap kelompok yang telah selesai di clustering dengan menentukan suatu kelompok masuk kategori Sangat Miskin (SM), Miskin (M), Rentan Miskin (RM) atau Tidak Miskin (TM). Untuk menentukan kategori setiap kelompok maka perlu beberapa variabel yang akan digunakan sebagai variabel yang dapat mengukur ke empat kategori diatas. Ada 8 variabel yang digunakan antara lain Status Tempat Tinggal, Atap Terluas, Dinding Terluas, Lantai Terluas, Sumber Penerangan Bahan Bakar, Fasilitas Tempat Buang Air Besar (BAB) dan Sumber Air Minum[19]. Masing-masing variabel memiliki kriteria tertentu untuk menentukan suatu cluster masuk kategori SM, M, RM dan TM. Dari setiap variabel memiliki kriteria masing-masing yaitu sebagai berikut : 
Tabel 4.1. Kriteria Variabel Untuk Pengkategorian Cluster

\begin{tabular}{|c|c|c|c|c|c|}
\hline $\begin{array}{l}\text { Variabel/ } \\
\text { Kriteria }\end{array}$ & $\mathrm{SM}$ & M & $\mathrm{RM}$ & TM & Penjelasan \\
\hline $\begin{array}{l}\text { Status Tempat } \\
\text { Tinggal }\end{array}$ & Dinas & Bebas Sewa & Kontrak & $\begin{array}{l}\text { Milik } \\
\text { Sendiri }\end{array}$ & - \\
\hline Atap & Jerami & Bambu & Asbes & Beton & $\begin{array}{l}\text { SM (Jerami dan lainnya), M (Bambu dan kayu), RM (Asbes } \\
\text { dan Seng), TM (Beton dan Genteng), }\end{array}$ \\
\hline Dinding & Bambu 3 & Bambu 2 & Bambu 1 & Tembok & $\begin{array}{l}\text { SM (Bambu dan lainnya), M (Bambu dan Batang Kayu, RM } \\
\text { (Plasteran anyaman bambu dan Kayu), TM (Tembok) }\end{array}$ \\
\hline Lantai & Bambu & Kayu & Ubin & Keramik & $\begin{array}{l}\text { SM (Bambu, Tanah dan lainnya), M (Kayu dan Semen/Bata } \\
\text { merah), RM (Parket dan Ubin), TM (Marmer dan Keramik), }\end{array}$ \\
\hline Penerangan & $\begin{array}{l}\text { Bukan } \\
\text { Listrik }\end{array}$ & Non PLN & PLN & PLN 1 & PLN 1 (PLN dengan Meteran) \\
\hline Bahan Bakar & $\begin{array}{l}\text { Minyak } \\
\text { Tanah }\end{array}$ & Kayu Bakar & Gas & $\begin{array}{l}\text { Listrik } \\
\text { Elpiji }\end{array}$ & $\begin{array}{l}\text { SM (Kayu Bakar, lainnya), M (Minyak tanah, Briket, Arang), } \\
\text { RM (Gas Kota, Biogas), TM (Listrik, Elpiji ( } 5.5 \mathrm{~kg}, 12 \mathrm{~kg}, 3 \\
\mathrm{~kg}) \text {, }\end{array}$ \\
\hline Fasilitas BAB & $\begin{array}{l}\text { Tidak } \\
\text { Ada }\end{array}$ & $\begin{array}{l}\text { Umum } \\
2\end{array}$ & Umum 1 & $\begin{array}{l}\text { Milik } \\
\text { Sendiri }\end{array}$ & $\begin{array}{l}\text { SM (Tidak Menggunakan dan Tidak ada fasilitas), M (Ada, } \\
\text { Umum) RM (Ada, digunakan dengan ART tertentu), TM } \\
\text { (Ada, Milik Sendiri), }\end{array}$ \\
\hline $\begin{array}{l}\text { Sumber Air } \\
\text { Minum }\end{array}$ & Sungai & $\begin{array}{l}\text { Sumur Tak } \\
\text { Terlindung }\end{array}$ & Leding & $\begin{array}{c}\text { Isi } \\
\text { Ulang }\end{array}$ & $\begin{array}{l}\text { SM (Mata Air Tidak Terlindung, Sungai, Air Hujan dil), M } \\
\text { (Sumur Tidak Terlindung, Mata Air Terlindung, Mata Air } \\
\text { Tak Terlindung), RM (Leding, Sumur Bor/Pompa, Sumur } \\
\text { Terlindung), TM (Air Kemasan Bermerk, Air Isi Ulang) }\end{array}$ \\
\hline
\end{tabular}

Untuk mencari kategori setiap kelompok, pada penelitian ini dilakukan secara manual yaitu menggunakan aplikasi Excel. Perhitungannya dilakukan dengan melihat setiap cluster yang memiliki jumlah data paling banyak/dominan dari setiap kriteria. Bila cluster 1 dan 2 sudah diketahui data mana yang paling dominan maka selanjutnya hanya membandingkan cluster 3 dan 4 . Hasil dari perhitungan di Excel dapat dilihat sebagai berikut

\section{a. Status Tempat Tinggal}

Tabel 4.2. Variabel Status Tempat Tinggal menggunakan K-means

\begin{tabular}{|c|c|c|c|c|}
\hline \multirow{2}{*}{ Cluster } & \multicolumn{4}{|c|}{ Status Tempat Tinggal } \\
\cline { 2 - 5 } & Dinas & Bebas Sewa & Kontrak & Milik Sendiri \\
\hline C0 & 9 & 299 & 85 & 2114 \\
\hline C1 & 96 & 154 & 319 & 1117 \\
\hline C2 & 118 & 387 & 154 & 4073 \\
\hline C3 & 220 & 220 & 194 & 2076 \\
\hline
\end{tabular}

Dari tabel diatas diperoleh grafik sebagai berikut : 


\section{Status Tempat Tinggal}

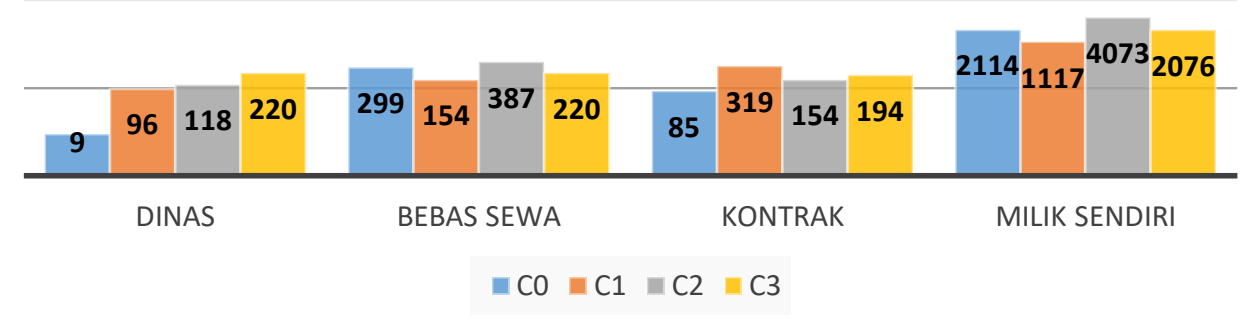

Grafik 4.1. Variabel Status Tempat Tinggal dengan K-means

Dari grafik diatas dapat dilihat bahwa data yang paling banyak padarumah dengan status Dinas adalah cluster 3,status bebas sewa pada cluster 2, status Kontrak pada cluster 1 dan status Milik Sendiri pada cluster 0 .

Dapat disimpulkan bahwa berdasarkan tabel status tempat tinggal menggunakan algoritma K-means didapatkan kategori Sangat Miskin berada di C3, Miskin berada di C2, Rentan Miskin berada di C1 dan Tidak Miskin C0.

Tabel 4.3. Variabel Status Tempat Tinggal menggunakan X-means

\begin{tabular}{|c|c|c|c|c|}
\hline \multirow{2}{*}{ Cluster } & \multicolumn{4}{|c|}{ Status Tempat Tinggal } \\
\cline { 2 - 5 } & Dinas & Bebas Sewa & Kontrak & Milik Sendiri \\
\hline C0 & 15 & 73 & 27 & 872 \\
\hline C1 & 2088 & 298 & 83 & 2088 \\
\hline C2 & 128 & 302 & 488 & 2347 \\
\hline C3 & 118 & 387 & 154 & 4073 \\
\hline
\end{tabular}

Dari tabel diatas diperoleh grafik sebagai berikut :

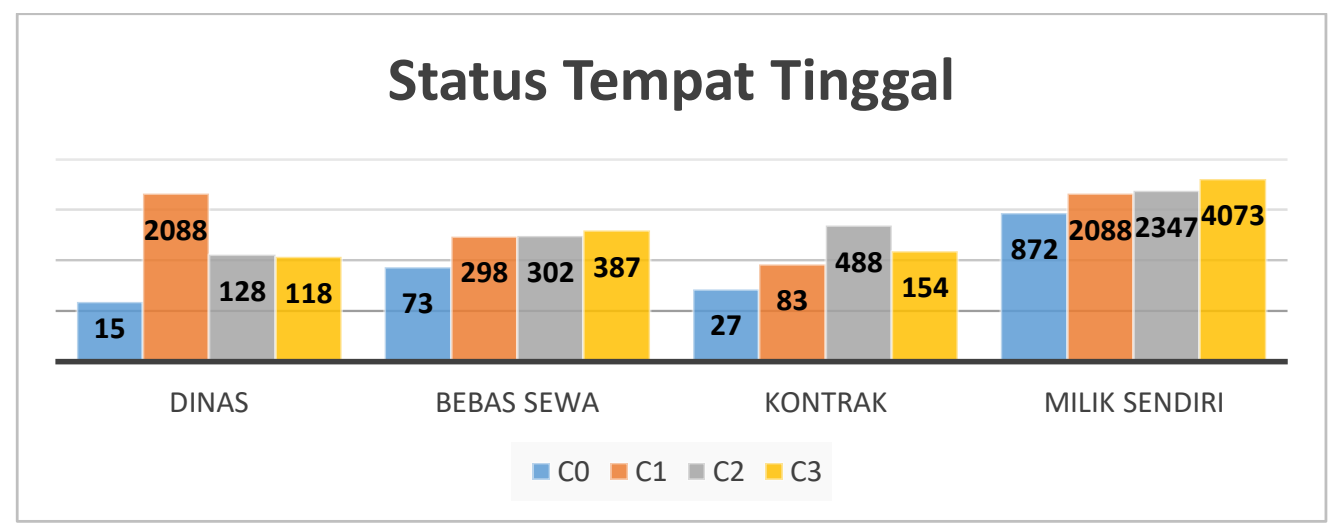

Grafik 4.2. Variabel Status Tempat Tinggal menggunakan X-means

Dari grafik diatas dapat dilihat bahwa data yang paling banyak pada rumah dengan status Dinas adalah cluster 1 , status bebas sewa pada cluster 3, status Kontrak pada cluster 2 dan status Milik Sendiri pada cluster 0 .

Dapat disimpulkan bahwa berdasarkan tabel status tempat tinggal menggunakan algoritma $X$-means didapatkan kategori Sangat Miskin berada di C1, Miskin berada di C3, Rentan Miskin berada di C2 dan Tidak Miskin C0.

Hasil kategori 8 variabel menggunakan algoritma $K$-means dan $X$-means dapat dilihat pada tabel dibawah 
Tabel 4.4. Perbandingan Hasil Kategori Setiap Variabel

\begin{tabular}{|l|c|c|c|c|c|c|c|c|}
\hline \multicolumn{1}{|c|}{$\begin{array}{c}\text { Algoritma / } \\
\text { Variabel }\end{array}$} & \multicolumn{4}{|c|}{ K-means } & \multicolumn{5}{c|}{ X-means } \\
\cline { 2 - 9 } & C0 & C1 & C2 & C3 & C0 & C1 & C2 & C3 \\
\hline S.T. Tinggal & TM & RM & M & SM & TM & SM & RM & M \\
\hline Atap & SM & TM & M & RM & RM & SM & TM & M \\
\hline Dinding & M & TM & SM & RM & RM & M & TM & SM \\
\hline Lantai & SM & RM & M & TM & TM & SM & RM & M \\
\hline S.Penerangan & SM & TM & M & RM & TM & SM & RM & M \\
\hline B. Bakar & M & RM & SM & TM & TM & M & RM & SM \\
\hline F. BAB & SM & TM & RM & M & TM & SM & M & RM \\
\hline S.A. Minum & SM & TM & M & RM & TM & SM & RM & M \\
\hline $\begin{array}{l}\text { Kategori } \\
\text { Dominan }\end{array}$ & SM & TM & M & RM & TM & SM & RM & M \\
\hline
\end{tabular}

Berdasarkan tabel diatas dapat dilihat bahwa pada algoritma $K$-means jumlah kategori paling banyak pada C0 yaitu kategori SM (warna biru)dengan jumlah sebanyak 5, pada C1 kategori paling banyak yaitu TM (warna merah) dengan jumlah sebanyak 5, pada C2 kategori paling banyak yaitu M (warna hijau) dengan jumlah sebanyak 5 dan pada C3 jumlah kategori paling banyak yaitu RM (warna biru muda) dengan jumlah 4.Untuk hasil kategori kedua algoritma dapat dilihat pada tabel 4.22 .

Tabel 4.5. Hasil Kategori

\begin{tabular}{|c|c|c|}
\hline Algoritma / Cluster & K-Means & X-Means \\
\hline Cluster 0 & Sangat Miskin & Tidak Miskin \\
\hline Cluster 1 & Tidak Miskin & Sangat Miskin \\
\hline Cluster 2 & Miskin & Rentan Miskin \\
\hline Cluster 3 & Rentan Miskin & Miskin \\
\hline
\end{tabular}

Dari tabel diatas dapat disimpulkan bahwa tingkatan kemiskinan pada algoritma $K$-means C0 merupakan kategori Sangat Miskin, C1 Tidak Miskin, C2 Miskin dan C3 Rentan Miskin. Sedangkan tingkatan kemiskinan pada algoritma $X$-means C0 merupakan kategori Tidak Miskin, C1 Sangat Miskin, C2 Rentan Miskin dan C3 Miskin.

\section{Kesimpulan dan Saran}

\subsection{Kesimpulan}

1. Berdasarkan pengujian menggunakan data Iris dengan algoritma $K$-means dan $X$-means, digunakan 2 metode untuk menilai keakuratan suatu cluster yaitu dengan purity dan DBI. Nilai purity yang diperoleh $K$-means yaitu 0.89 dan $X$-means 0.88 serta nilai DBI yang didapat dari kedua algoritma memiliki nilai yang sama yaitu 0.16 . Waktu yang diperlukan untuk pengelompokan sangat cepat yaitu 0.02 pada $\mathrm{K}$ means dan 0.00000001 pada $X$-means. Dari pengujian tersebut algoritma $K$-means dan $X$-means cocok digunakan untuk melakukan pengelompokan karena memiliki tingkat akurasi yang baik dengan nilai purity yang mendekati 1 dan nilai DBI yang mendekati 0 serta tidak membutuhkan waktu yang lama dalam proses pengelompokan.

2. Pada pengelompokan data BPS waktu yang diperoleh pada algoritma $X$-means lebih cepat daripada $K$ means yaitu 0.22 pada $K$-means dan 0.06 pada $X$-means. $X$-means memiliki kelebihan pada jumlah iterasi yang tidak banyak sehingga membuat proses pengelompokan menjadi lebih cepat.

3. Data iris kurang tepat jika dikelompokan menggunakan $X$-means karena jumlah data yang sedikit mempengaruhi jumlah kelompok yang dihasilkan.

4. Berdasarkan pengelompokan data BPS menggunakan algoritma K-means dan $X$-means didapatkan tingkatan kemiskinan menggunakan algoritma $K$-meansyaitu Sangat Miskin berada pada cluster 0, Miskin berada pada cluster 2, Rentan Miskin berada pada cluster 3 dan Tidak Miskin berada pada cluster 1 . Sedangkan menggunakan algoritma $X$-means didapatkan tingkatan kemiskinan yaitu Sangat Miskin berada pada cluster 1, Miskin berada pada cluster 3, Rentan Miskin cluster 2 dan Tidak Miskin berada pada cluster 0 .

\subsection{Saran}

Saran yang dapat diberikan untuk pengembangan penelitian selanjutnya adalah : 
1. Dalam penelitian ini hanya menggunakan aplikasi Weka dalam melakukan pengelompokan. Diharapkan pada penelitian selanjutnya dapat menggunakan aplikasi tambahan untuk mengukur serta memperkuat perbandingan tingkat akurasi dari masing-masing algoritma. Disarankan membandingkan algortima $X$-means dengan aplikasi berbeda Seperti Rapid Miner, MAT LAB, RStudio dll.

2. Untuk mengelompokan data yang sedikit serta sudah diketahui jumlah kelompoknya disarankan untuk menggunakan $K$-means.

3. Untuk penelitian selanjutnya dapat menggunakan data yang lebih banyak lagi, untuk mengetahui jumlah iterasi dan tingkat kecepatan dalam melakukan pengelompokan.

\section{Daftar Pustaka}

[1] D. R. Utami, “APLIKASI MONITORING KELUARGA MISKIN MENGGUNAKAN METODE KMEANS CLUSTERING BERBASIS MOBILE GIS ( STUDI KASUS: PKH KEC KEDUNGKANDANG KOTA MALANG ) SKRIPSI Oleh : DWI RAHAYU UTAMI.” pp. 1-110, 2018.

[2] News.detik.com, "Peringkat Kemiskinan di Sumatera: Aceh Tertinggi, Kepri Terendah.” 2019.

[3] https://baitulmal.acehprov.go.id, "Pendidikan." 2019.

[4] L. K. Damayanti, "APLIKASI ALGORITMA CART UNTUK MENGAKLASIFIKASIKAN DATA NASABAH ASURANSI JIWA BERSAMA BUMIPUTERA 1912 SURAKARTA,” no. July. p. 92, 2011.

[5] P. Subarkah, "Perbandingan Kinerja Algoritma Cart dan Naive Bayesian untuk Mendiagnosa Penyakit Diabetes Melitus," p. 17, 2016.

[6] W. Isdijoso and A. Suryahadi, "Penetapan Kriteria dan Variabel Pendataan Penduduk Miskin yang Komprehensif dalam Rangka Perlindungan Penduduk Miskin di Kabupaten / Kota.” pp. 1-25, 2016.

[7] N. R. S. Purba and F. Riandari, "Implementasi Data Mining Menggunakan Algoritma Apriori Untuk Analisis Keranjang Belanja Transaksi Penjualan Pada PT Madu Kembang Joyo,” J. Nas. Komputasi dan Teknol. Inf., vol. 4, no. 1, 2021.

[8] N. F. Kahar, L. Hadjaratie, S. Suhada, and I. R. Padiku, "I MPLEMENTASI D ATA M INING D ALAM P ENENTUAN T INGKAT K EMISKINAN M ENGGUNAKAN F UZZY C-M EANS,” pp. 1-10.

[9] R. Awaliah, “ANALISIS CLUSTERING UNTUK MENGELOMPOKKAN TINGKAT KESEJAHTERAAN KABUPATEN/KOTA BERDASARKAN SOSIAL EKONOMI RUMAH TANGGA DI WILAYAH PROVINSI SULAWESI SELATAN.” pp. 1-86, 2018.

[10] F. Yunita, "Penerapan Data Mining Menggunkan Algoritma K-Means Clustring Pada Penerimaan Mahasiswa Baru," Sistemasi, vol. 7, no. 3, p. 238, 2018.

[11] NUR ARISKA, “ANALISIS CLUSTER DENGAN METODE ENSEMBLE ROCK UNTUK DATA BERSKALA CAMPURAN KATEGORIK DAN NUMERIK.” pp. 1-113, 2017.

[12] S. M. Hutabarat and A. Sindar, "Data Mining Penjualan Suku Cadang Sepeda Motor Menggunakan Algoritma K-Means,” J. Nas. Komputasi dan Teknol. Inf., vol. 2, no. 2, pp. 126-132, 2019.

[13] R. Fatah, "Perancangan Model Prediksi Kelulusan Mahasiswa Tepat Waktu pada UIN Raden Fatah," vol. 4, pp. 49-62, 2018.

[14] T. Mardiana, R. D. Nyoto, P. Studi, and T. Informatika, "Kluster Bag-of-Word Menggunakan Weka," vol. 1, no. 1, pp. 1-5, 2015.

[15] A. Wijayanto and R. Adhitama, "Penggunaan X-Means Clustering Method untuk Mengelompokkan Potensi Sekolah Menengah Unggul di Kabupaten Banyumas,” vol. 2, no. 1, p. 9, 2019.

[16] B. Yusuf, "Analisis dan perbandingan kualitas pengelompokan dokumen ( document clustering ) dengan menggunakan metode k-means dan k-medians bustami yusuf," vol. 1, no. 2, pp. 1-10, 2015.

[17] E. P. A. Pratiwi, Lhorend Mutiara, Diana, "PENERAPAN K-MEANS CLUSTERING UNTUK MEMPREDIKSI MINAT NASABAH PADA PT . ASURANSI JIWA BERSAMA 1912 BUMIPUTERA PRABUMULIH Lhorend Mutiara Pratiwi ${ }^{1}$, Diana ${ }^{2}$, Eka Puji Agustini ${ }^{3}$ Dosen Universitas Bina Darma ${ }^{2}$ . ${ }^{3}$, Mahasiswa Universitas Bina Darma ${ }^{1}$ Jalan Jend," p. 16.

[18] T. Suharseno, R. Hidayat, D. Ayu, and L. Dewi, "KATEGORI PRODUK TERHADAP KEPUTUSAN PERPINDAHAN MEREK DENGAN KEBUTUHAN MENCARI VARIASI SEBAGAI,” vol. 18, no. 2, pp. 176-182, 2013.

[19] A. Sitepu, "KARAKTERISTIK KELUARGA MENURUT PERINGKAT KEMISKINAN: STUDI PENDAHULUAN UNTUK PERUMUSAN KRITERIA FAKIR MISKIN (Family characteristics ratings by poverty: preliminary studies for the formulation of criteria for poor people)," vol. 17, no. 01. 